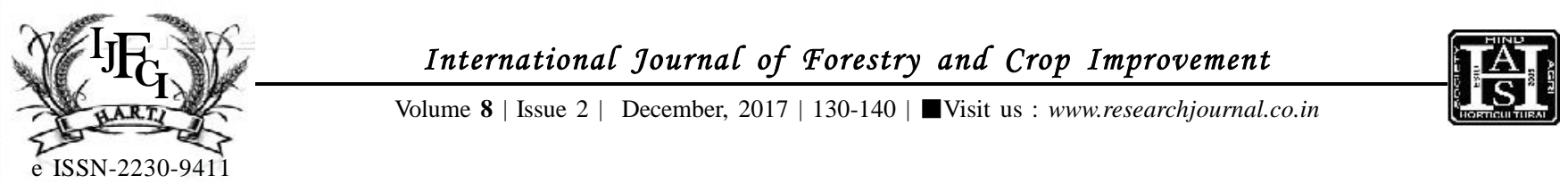

\title{
Study of association of soil parameters with various site quality classes of forests of Mukundpur, Satna, Forest Division, Madhya Pradesh, India
}

\author{
PRACHISINGH
}

\begin{abstract}
Mukundpur forest range is situated in Amarpatan Tahsil of Satna district of Madhya Pradesh India. The range has geographical area of $589.71 \mathrm{~km}^{2}$ with forest area $111.55 \mathrm{~km}^{2}$. This area is under high disturbances and ecological stress due to manmade activities, the associations of soil parameters like $\mathrm{pH}$, electrical conductivity, availability of major nutrients (Nitrogen, phosphorus and potassium) and micro nutrients like (Copper, manganese, iron and zinc) with site quality are analyzed. Individual effects of $\mathrm{pH}, \mathrm{EC}$ and Organic Carbon play the significant role in site quality classes of study area i.e. these soil parameters affect the productivity of the forest individually. The combined impact of $\mathrm{pH}, \mathrm{EC}$ and organic carbon does have significant association within various site quality classes of study area. Except encroachment category class, individually nitrogen and $\mathrm{P}_{2} \mathrm{O}_{5}$ does not make significant impact on various site quality classes, though individually $\mathrm{K}_{2} \mathrm{O}$ does have significant impact on site quality class of IVA and VA. The combined impact of Nitrogen, $\mathrm{P}_{2} \mathrm{O}_{5}$ and $\mathrm{K}_{2} \mathrm{O}$ (macro nutrients) do have significant association within various site quality classes of study area. Thus combined effects of macro nutrient of soil have significant bearing on forest productivity of study area. Except encroachment, individual $\mathrm{Zn}$ do not have significant impact on various site quality classes, though results of Fe shows significant role in site quality IVA individually. Individually the manganese does not play the significant role in site quality IVB and VA but this has strong influence on other site quality classes. Individually $\mathrm{Cu}$ does have significant in encroachment and site quality IVA but it does not have significant role in other site quality classes. The overall impact of $\mathrm{Zn}, \mathrm{Fe}, \mathrm{Mn}$ and $\mathrm{Cu}$ do not have significant association within various site quality classes of study area. Thus overall impact of micro nutrient does not have significant association in productivity of forests.
\end{abstract}

KEY WORDS : Site quality, pH, Electrical conductivity, Organic carbon content, Macro nutrients, Micro nutrients

HOW TO CITE THIS ARTICLE : Singh, Prachi (2017). Study of association of soil parameters with various site quality classes of forests of Mukundpur, Satna, Forest Division, Madhya Pradesh, India. Internat. J. Forestry \& Crop Improv., 8 (2) : 130-140, DOI: 10.15740/HAS/ IJFCI/8.2/130-140.

Article Chronical : Received : 13.10.2017; Revised : 10.11.2017; Accepted : 26.11.2017 